Article

\title{
pH-Induced Folding of the Caspase-Cleaved Par-4 Tumor Suppressor: Evidence of Structure Outside of the Coiled Coil Domain
}

\author{
Andrea M. Clark, Komala Ponniah, Meghan S. Warden, Emily M. Raitt, Andrea C. Yawn and \\ Steven M. Pascal ${ }^{1, *}$ \\ Department of Chemistry and Biochemistry, Old Dominion University, Norfolk, VA 23529, USA; \\ akorell@odu.edu (A.M.C.); kponniah@odu.edu (K.P.); mwarden@odu.edu (M.S.W.); erait001@odu.edu (E.M.R.); \\ ayawn@odu.edu (A.C.Y.) \\ * Correspondence: spascal@odu.edu; Tel.: +757-683-6763
}

Received: 10 October 2018; Accepted: 22 November 2018; Published: 4 December 2018

\begin{abstract}
Prostate apoptosis response-4 (Par-4) is a $38 \mathrm{kDa}$ largely intrinsically disordered tumor suppressor protein that functions in cancer cell apoptosis. Par-4 down-regulation is often observed in cancer while up-regulation is characteristic of neurodegenerative conditions such as Alzheimer's disease. Cleavage of Par-4 by caspase- 3 activates tumor suppression via formation of an approximately $25 \mathrm{kDa}$ fragment (cl-Par-4) that enters the nucleus and inhibits Bcl-2 and NF- $\kappa \mathrm{B}$, which function in pro-survival pathways. Here, we have investigated the structure of cl-Par-4 using biophysical techniques including circular dichroism (CD) spectroscopy, dynamic light scattering (DLS), and intrinsic tyrosine fluorescence. The results demonstrate $\mathrm{pH}$-dependent folding of cl-Par-4, with high disorder and aggregation at neutral $\mathrm{pH}$, but a largely folded, non-aggregated conformation at acidic $\mathrm{pH}$.
\end{abstract}

Keywords: prostate apoptosis response-4 (Par-4); intrinsically disordered protein (IDP); cancer; circular dichroism; coiled coil (CC), leucine zipper (LZ), apoptosis

\section{Introduction}

Par-4 is a pro-apoptotic tumor suppressor protein that was first identified in studies of prostate cancer [1-3]. In normal mammalian tissue, Par-4 is ubiquitously expressed, localized in the cytoplasm of healthy cells, and spontaneously secreted $[1,2,4,5]$. Par-4 down-regulation has been implicated in a variety of cancers including prostate, renal, breast, endometrial, leukemia, and neuroblastoma [6-9]. Furthermore, low Par-4 levels correlate to metastasis and an increased chance of cancer recurrence $[8,10]$. The Par-4/PAWR gene is found on the unstable chromosome 12q21.2, which is often mutated or deleted in cancers such as gastric and pancreatic [11].

The most well characterized mode of cancer cell apoptosis induced by extracellular Par-4 is mediated via interaction of Par-4 with the cell surface GRP78 protein [4]. This interaction initiates the apoptotic Fas/FasL-FADD caspase-8 pro-death pathway $[4,12,13]$. Healthy cells have low cell surface levels of GRP78, providing resistance to extracellular Par-4-induced apoptosis [4,14]. Par-4 can also induce cancer cell apoptosis intracellularly via nuclear translocation of a C-terminal fragment, as discussed further below $[10,15,16]$.

Par-4 contains two nuclear localization sequences (NLS1 and NLS2), a VASA domain (a sequence similar to that found in the VASA protein), a selective for apoptosis induction in cancer cells (SAC) domain, a coiled coil (CC) domain with a leucine zipper (LZ), and a nuclear export sequence (NES) $[2,5,17]$. The SAC domain is the minimum fragment necessary to induce 
apoptosis [17-19]. The C-terminal CC plays a role in homo- and hetero-dimerization and regulation of Par-4 function [2,18,20-23].

The Par-4 CC contains approximately 78 amino acids, with the C-terminal half of the CC displaying a marked heptad repeat characteristic of a LZ [5]. The isolated C-terminal LZ can interconvert between a partially ordered monomer (POM) and a coiled coil dimer (CCD) [21,22]. The LZ associates tighter under acidic conditions, forming a more stable dimer [24,25]. Dimer formation in the entire CC domain was confirmed by $x$-ray crystallography [23]. However, little is known about the structure of the remainder of the protein except that most of full-length Par-4, outside of the CC, appears to be disordered in vitro [21,22]. Intrinsically disordered proteins (IDPs) lack a stable structure and many disease-associated proteins can be classified as IDPs [26-29].

Caspase-3-mediated cleavage of Par-4 at Asp-131 generates two fragments: a $15 \mathrm{kDa}$ amino-terminal fragment ("PAF" Par-4 Amino terminal Fragment) and a $25 \mathrm{kDa}$ C-terminal fragment, cleaved Par-4 (cl-Par-4) [30,31]. The PAF contains the NLS1 and VASA segment and remains in the cytoplasm [17,32-35]. cl-Par-4 retains the SAC domain (residues 16-71) that includes NLS2, the CC with LZ (133-211), and a linker domain (72-132) connecting the SAC and CC domains, where numbering is in the context of the fragment (Figure 1a) [17,30]. cl-Par-4 translocates to the nucleus via NLS2 [5], where it inhibits pro-survival pathways that mediate cancer cell survival including NF- $\kappa \mathrm{B}$ and Bcl-2 $[13,16,17,30,34,36]$. cl-Par-4 is an attractive therapeutic target because of its potential to specifically target cancer cells.

a)

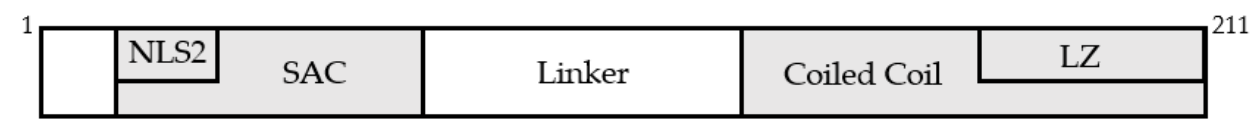

b)

c)
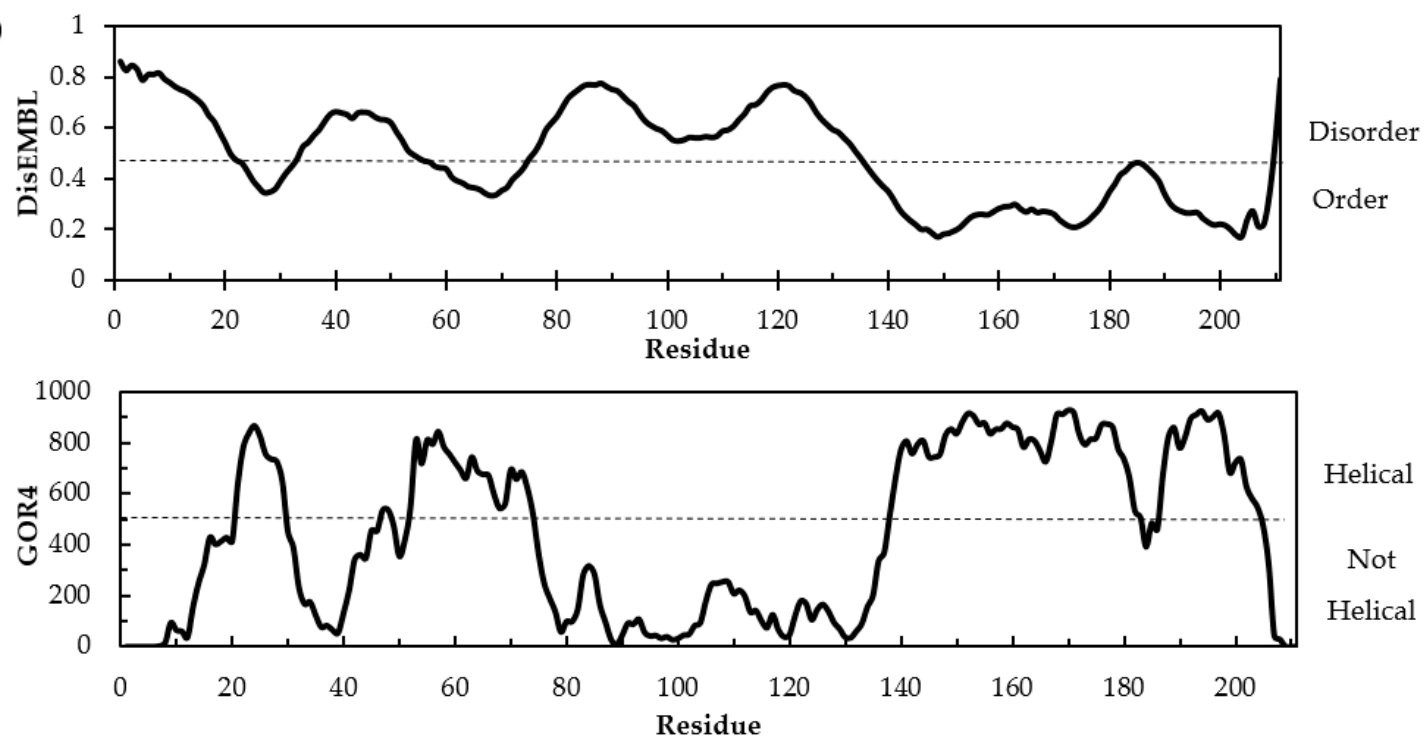

Figure 1. (a) Block diagram of caspase-3-cleaved Par-4 (cl-Par-4) domain structure. (b) DisEMBL disorder prediction. (c) GOR4 (Garnier-Osguthorpe-Robson) alpha helix prediction.

Here, we have studied the conformation of cl-Par-4 in vitro. Results show that at neutral $\mathrm{pH}$, cl-Par-4 forms partially folded, soluble aggregates with a high degree of conformational flexibility. In contrast, at acidic $\mathrm{pH}$, cl-Par-4 adopts a predominantly folded, stable, largely alpha helical conformation. While the CC has been previously structurally characterized, this is the first evidence of structure outside of the CC domain in Par-4. These observations have implications for understanding cl-Par-4 structure and function in relation to cellular localization. 


\section{Materials and Methods}

\subsection{Expression and Purification of cl-Par-4}

The cl-Par-4 construct (residues 132-340 of human Par-4) was prepared by PCR amplification with the following primers: 5'-GACCCATGGGTGTTCCGGAGAAGGGCAAAAGC-3' (forward) and 5'-CAGAAGCTTTTAGCGGGTCAGTTGGCCCACCAC-3' (reverse) using full length Par-4 as a template. PCR primers were purchased from Eurofins Genomics (Louisville, KY, USA). The PCR product was cleaved with NcoI/HindIII and ligated into a modified version of the expression vector H-MBP-3C [37]. DNA sequence of the construct was verified through sequencing and protein expression was carried out in BL21 (DE3) CodonPlus cells. The cells were grown in Luria-Burtani (LB) media with $100 \mu \mathrm{g} / \mathrm{mL}$ ampicillin at $37^{\circ} \mathrm{C}$ until an $\mathrm{OD}_{600}$ of $0.8-0.9$ was reached. Protein expression was induced with the addition of $0.5 \mathrm{mM}$ isopropyl thio- $\beta$-D-galactoside (IPTG) and then grown for an additional $18 \mathrm{~h}$ at $15^{\circ} \mathrm{C}$.

The cells were harvested by centrifugation and the resulting cell pellet was resuspended in lysis buffer (10 mM Tris, $300 \mathrm{mM} \mathrm{NaCl,} 20 \mathrm{mM}$ imidazole, $1 \mathrm{mM}$ TCEP, pH 7.4) containing $1 \mathrm{mg} / \mathrm{mL}$ lysozyme. Cells in lysis buffer were sonicated with a $10 \mathrm{~s}$ pulse $/ 59 \mathrm{~s}$ rest at $40 \%$ amp for 30 repetitions, followed by centrifugation at $16,000 \mathrm{rpm}$. The lysate was filtered through a $0.8 \mu \mathrm{m}$ syringe filter, followed by filtration with a $0.45 \mu \mathrm{m}$ filter. The clarified cell lysate was then purified with IMAC using a His-Trap HP column (GE Healthcare, Uppsala, Sweden) and eluted with buffer containing $300 \mathrm{mM}$ imidazole. Fractions containing the protein of interest were pooled and dialyzed in $3 \mathrm{C}$ protease cleavage buffer (10 mM Tris, $1 \mathrm{M} \mathrm{NaCl}, 1 \mathrm{mM}$ TCEP, $\mathrm{pH}$ 7.5). The His-MBP tag was removed by cleavage with $3 \mathrm{C}$ protease at $4{ }^{\circ} \mathrm{C}$ in $3 \mathrm{C}$ protease cleavage buffer. Cleavage left a two-residue remnant (Gly-Pro) at the N-terminus of cl-Par-4. As a final purification step the cleaved product was dialyzed against $10 \mathrm{mM}$ Tris, $1 \mathrm{M} \mathrm{NaCl}, 20 \mathrm{mM}$ imidazole and $1 \mathrm{mM}$ TCEP, pH 8.0 and loaded onto a His-Trap $\mathrm{HP}$ column to remove the tag.

Purified cl-Par-4 was dialyzed against $10 \mathrm{mM}$ Tris, $1 \mathrm{M} \mathrm{NaCl}, 1 \mathrm{mM}$ TCEP, pH 7.0, and then concentrated by centrifugation at $3500 \mathrm{rpm}$ using a Vivaspin Turbo 15 (Sartorius, Epsom, UK). Absorbance measurements at $280 \mathrm{~nm}$ were taken to determine protein concentration using the extinction coefficient $6400 \mathrm{M}^{-1} \mathrm{~cm}^{-1}$. Purified cl-Par-4 was lyophilized in $10 \mathrm{mM}$ Tris, $1 \mathrm{M} \mathrm{NaCl}$, $1 \mathrm{mM}$ TCEP, $\mathrm{pH}$ 7.0, and re-solubilized in sterile distilled $\mathrm{H}_{2} \mathrm{O}$. TCEP was used in the purification steps to prevent aggregation via disulfide bond formation.

The theoretical molecular weight of the bacterially expressed cl-Par-4 used for this study was $24 \mathrm{kDa}$, but has been approximated as $25 \mathrm{kDa}$ throughout this manuscript for consistency with prior literature, where the molecular weight was determined via Western blots performed with mammalian extracts [30].

\subsection{Circular Dichroism Measurements}

Circular dichroism (CD) spectra were recorded on a J-815 CD spectrometer (Jasco, Easton, MD, USA). Samples were at a concentration of $0.2 \mathrm{mg} / \mathrm{mL}$ in native buffer $(20 \mathrm{mM} \mathrm{NaCl}, 10 \mathrm{mM}$ Tris, $1 \mathrm{mM}$ TCEP) and native buffer with $0.1 \%$ SDS, ranging from $\mathrm{pH} 4-10$. Far UV-CD spectra were recorded from 260-190 $\mathrm{nm}$ at a scan speed of $20 \mathrm{~nm} / \mathrm{min}$ with a bandwidth of $1 \mathrm{~nm}$. Samples were recorded at $25^{\circ} \mathrm{C}$ unless otherwise noted. Thermal stability was probed by recording CD spectra at 5, 25, 45, 65, and $85^{\circ} \mathrm{C}$. Three scans were recorded for each sample and then averaged after baseline subtraction. The scans were smoothed using a means-movement function of 25. CD spectra were deconvoluted using the Selcon3 algorithm through the DichroWeb server [38].

\subsection{Dynamic Light Scattering and Zeta Potential Measurements}

DLS measurements were recorded using a NanoBrook Omni particle sizer and zeta potential analyzer (Brookhaven Instruments Corporation, Holtsville, NY, USA). Samples were at a concentration of $0.2 \mathrm{mg} / \mathrm{mL}$ in native buffer over a $\mathrm{pH}$ range from 4-10. DLS data was obtained at $25^{\circ} \mathrm{C}$ using $1 \mathrm{~cm}$ 
path length plastic cuvettes. Five scans were recorded and averaged for each sample. The highest peak of the histogram was recorded as the mean diameter for that sample and the hydrodynamic radius was calculated using the Stoke-Einstein equation. The cl-Par-4 zeta potential measurements were also recorded at a concentration of $0.2 \mathrm{mg} / \mathrm{mL}$ in native buffer over $\mathrm{pH} 4-10$. Five measurements in $\mathrm{mV}$ were recorded and averaged for each $\mathrm{pH}$, and the experimental $\mathrm{pI}$ was determined.

\subsection{Fluorescence Spectroscopy}

Fluorescence measurements were recorded using a Varian Cary Eclipse Fluorescence Spectrophotometer (Varian Inc., Santa Clara, CA, USA). Samples were at a concentration of $0.2 \mathrm{mg} / \mathrm{mL}$ in native buffer at $\mathrm{pH} 4$ and 7 in $1 \mathrm{~cm}$ path length, $400 \mu \mathrm{L}$ fluorescence cuvettes. Tyrosine was selectively excited at $220 \mathrm{~nm}$ (determined as the maximum excitation wavelength) and the emission spectrum was recorded over $250-400 \mathrm{~nm}$. An excitation slit width of $10 \mathrm{~nm}$ and an emission slit width of $20 \mathrm{~nm}$ was used. Three scans were recorded and averaged after baseline subtraction for each sample at $25^{\circ} \mathrm{C}$. For thermal denaturation studies, the fluorescence intensity at $310 \mathrm{~nm}$ was recorded from $20-95^{\circ} \mathrm{C}$ with a temperature rate increase of $1^{\circ} \mathrm{C} / \mathrm{min}$ using the same excitation and slit parameters as above.

\section{Results}

\subsection{Sequence Analysis and Structure Predictions}

Disorder prediction in cl-Par-4 was performed using DisEMBL analysis (Figure 1b). Disorder probability greater than 0.43 (dashed line) approximately separates order and disorder [39]. The data show high disorder probability in the linker domain with mixed order and disorder in the SAC domain. The region with the most order aligns with the CC and LZ.

Secondary structure prediction was performed using GOR4 analysis, which predicted $48.8 \%$ helical content, $41.7 \%$ random coil, and 9.5\% extended strand in cl-Par-4 [40]. Figure 1c shows alpha helix prediction using GOR4 (Garnier-Osguthorpe-Robson) analysis. Some helical propensity occurred in the SAC domain, while very low helicity was predicted in the linker domain. The highest helical propensity occurs in the CC and LZ. However, between residues 180-190, a decrease in helical propensity could be seen. This decrease corresponds to the position of a charge-charge repulsion across the CC dimer interface [24,25], as will be discussed further below. The regions with high disorder probability by DisEMBL aligns with regions of low helical propensity by GOR4.

At neutral $\mathrm{pH}, \mathrm{cl}-\mathrm{Par}-4$ is comprised of $19.9 \%$ negatively charged amino acids and $18.5 \%$ positively charged residues. This is significantly higher than the observed averages for vertebrate proteins: $11.7 \%$ and $11.4 \%$ for negatively and positively charged residues, respectively [41,42]. In general, high charge content in IDPs can contribute to the formation of extended conformations that minimize electrostatic repulsion between like charges [28]. Sodium dodecyl sulfate polyacrylamide gel electrophoresis (SDS-PAGE) of cl-Par-4 displays an apparent molecular weight of $31 \mathrm{kDa}$, approximately $30 \%$ higher than the expected molecular weight of $25 \mathrm{kDa}$ (Figure S1). Differential SDS-binding coupled with the fully extended conformation of IDPs can cause slower electrophoretic mobility [26,43,44].

\subsection{Secondary Structure Characterization by CD Spectroscopy}

The secondary structure of cl-Par-4 was investigated using CD spectroscopy under varying $\mathrm{pH}$ conditions (Figure 2a). A pair of minima at $222 \mathrm{~nm}$ and $208 \mathrm{~nm}$ are characteristic of alpha helical secondary structure. These minima were observed both under neutral conditions ( $\mathrm{pH} 7$ ) and more extreme conditions ( $\mathrm{pH} 4$ and $\mathrm{pH}$ 10). However, the CD spectrum at $\mathrm{pH} 4$ showed significantly more alpha helical character with intense negative transitions at these wavelengths. Helical content was lower at pH 7 and 10, as indicated by less intense dichroism at both $222 \mathrm{~nm}$ and $208 \mathrm{~nm}$. The CD spectra of cl-Par- 4 was also examined under denaturing conditions of $0.1 \%$ SDS to assess the mostly unfolded state for comparison. With $0.1 \%$ SDS, an intense minimum at $205 \mathrm{~nm}$ dominated the 
spectrum, though a second feature appeared near $222 \mathrm{~nm}$. This spectrum is characteristic of a mostly disordered conformation with a degree of residual secondary structure.

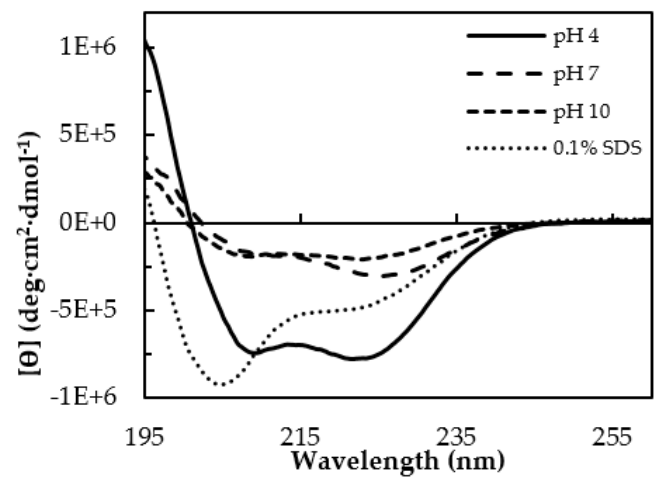

(a)

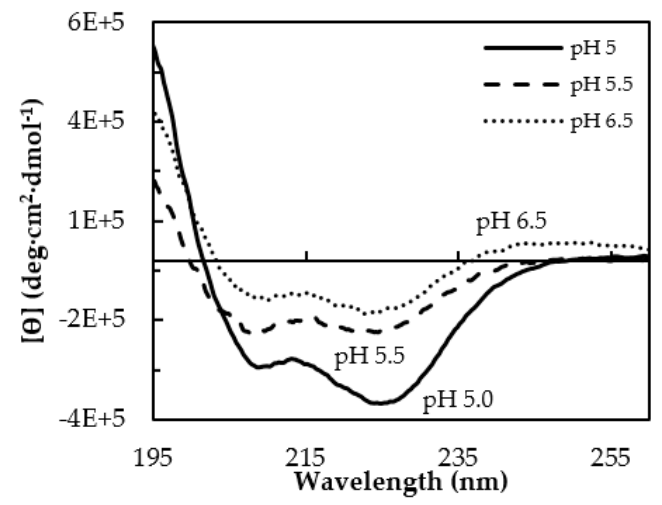

(c)

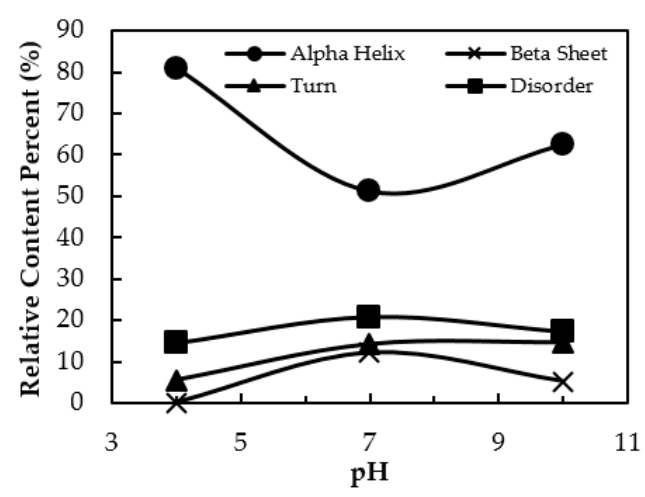

(b)

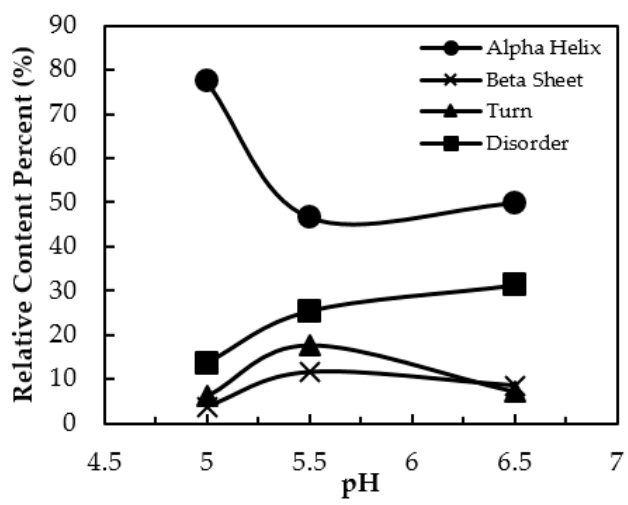

(d)

Figure 2. (a) Circular dichroism (CD) analysis of cl-Par-4 at pH 4, 7, 10, and in SDS (sodium dodecyl sulfate). (b) Secondary structure content at $\mathrm{pH} 4,7$ and 10. (c) $\mathrm{CD}$ analysis at $\mathrm{pH} 5,5.5$, and 6.5, near the pI. (d) Secondary structure content near the pI.

Consistent with the two intense minima at $\mathrm{pH} 4$, spectral deconvolution indicated an alpha helical content of $81 \%$, with a $14 \%$ disorder (Figure $2 \mathrm{~b}$ ). Beta sheet or turn content was minimal. At neutral $\mathrm{pH}$, calculations showed cl-Par-4 to be only about $\frac{1}{2}$ alpha helical, with $30 \%$ beta content (sheet + turn) and $22 \%$ disorder. At $\mathrm{pH} 10$, an intermediate level of alpha helix (62\%) with $15 \%$ turn and $17 \%$ disorder was calculated. The unfolded state in SDS was calculated to possess three approximately equal parts of $1 / 3$ alpha helical character, $1 / 3$ beta character, and $1 / 3$ disorder.

A ratio of $\theta_{222} / \theta_{208}$ greater than 1 is characteristic of CC formation [45]. Ratios were 1.2, 1.6, and 1.1 at $\mathrm{pH}$ 4, 7, and 10, respectively (Table S1), and each suggest some level of dimeric association of helices. The high ratio at $\mathrm{pH} 7$ could be influenced by the increased level of beta secondary structure, which can augment the dichroism at $222 \mathrm{~nm}$. Under SDS denaturing conditions, the $\theta_{222} / \theta_{208}$ ratio was 0.60 , which was not suggestive of CC formation, and disorder was increased. Together, the data suggest that low $\mathrm{pH}$ induces a well-folded $\mathrm{CC}$ and possibly additional non-coiled helices, while $\mathrm{pH} 7$ and 10 also induce some CC formation, but with additional beta-like and disordered content.

The CD spectra in Figure 2a show a marked difference in secondary structure above vs. below the cl-Par-4 theoretical isoelectric point (pI) of 5.39. To further investigate the conformation near the $\mathrm{pI}$, additional CD spectra were recorded at $\mathrm{pH} 5.0,5.5$, and 6.5 (Figure 2c), with secondary structure deconvolution charted in Figure 2d. Data were not acquired at pH 6.0 due to sample aggregation. Below the $\mathrm{pI}$ at $\mathrm{pH} 5.0$, a characteristic alpha helical spectrum indicated an approximately $80 \%$ helical content, with a $\theta_{222} / \theta_{208}$ ratio of 1.3 , consistent with the formation of CC (Table S2). In contrast, the spectra recorded above the $\mathrm{pI}$ both indicated approximately $50 \%$ helix. A lower $\theta_{222} / \theta_{208}$ ratio 
of 1.0 was observed at $\mathrm{pH} 5.5$, which was close to the $\mathrm{pI}$. The ratio was 1.3 at $\mathrm{pH} 6.5$; however, as discussed above, increased levels of beta secondary structure could affect this ratio. These results confirm additional helicity induced by $\mathrm{pH}$ below the $\mathrm{pI}$ value.

Next, the thermal dependence of the Far UV-CD spectrum at pH 7 and $\mathrm{pH} 4$ were compared (Figure 3). At $5{ }^{\circ} \mathrm{C}$, the $\mathrm{CD}$ spectra at $\mathrm{pH} 7$ showed an intense minimum near $225 \mathrm{~nm}$, but less intensity near $208 \mathrm{~nm}$ (Figure 3a). The spectral changes were modest through to $45^{\circ} \mathrm{C}$, then a major change occurred at $65{ }^{\circ} \mathrm{C}$ and $85^{\circ} \mathrm{C}$, with an intense band arising near $200 \mathrm{~nm}$, characteristic of disorder. In contrast, spectra at $\mathrm{pH} 4$ showed more alpha helical content, with intense minima at both 208 and $222 \mathrm{~nm}$ (Figure 3b). The spectra at pH 4 was consistent with a predominantly folded, alpha helical conformation even up to $65^{\circ} \mathrm{C}$, with significant disorder only arising at $85^{\circ} \mathrm{C}$.

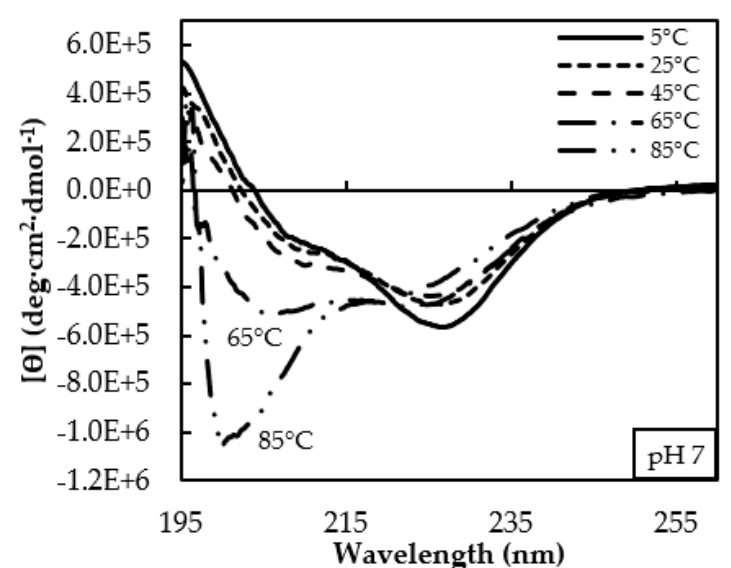

(a)

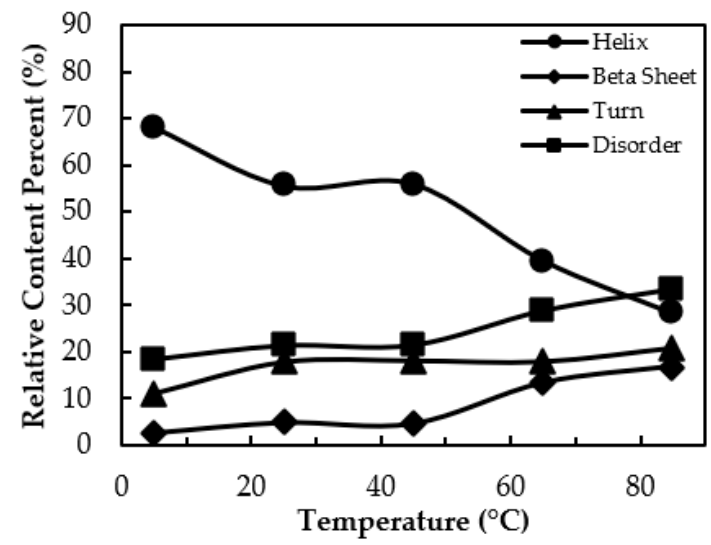

(c)

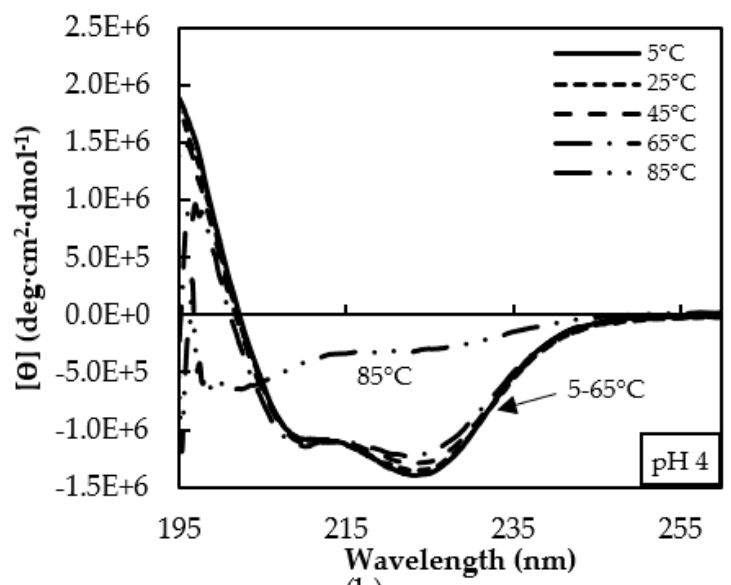

(b)

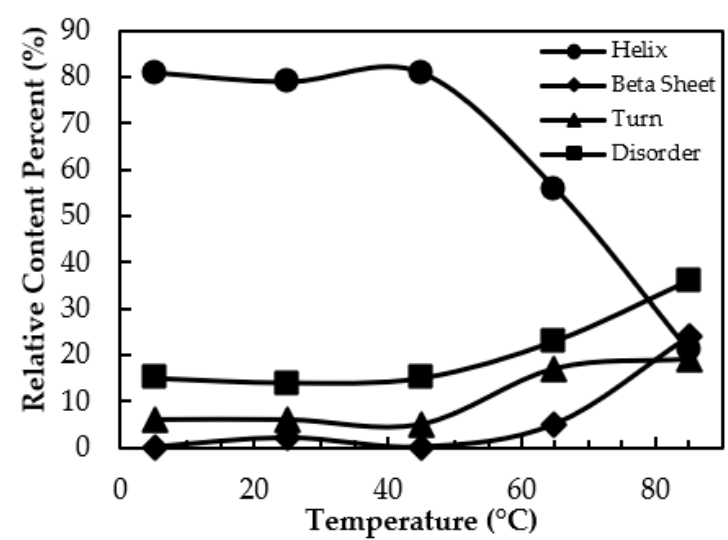

(d)

Figure 3. (a) Circular dichroism (CD) versus temperature at $\mathrm{pH}$ 7. (b) $\mathrm{CD}$ versus temperature at $\mathrm{pH}$ 4.(c) Secondary structure versus temperature at $\mathrm{pH}$ 7. (d) Secondary structure versus temperature at $\mathrm{pH} 4$.

At neutral $\mathrm{pH}$ and $5{ }^{\circ} \mathrm{C}$, there was approximately $2 / 3$ calculated helical content with $20 \%$ disorder (Figure 3c). Between $25-45^{\circ} \mathrm{C}$, helical content decreased to approximately $1 / 2$ with a corresponding increase in beta content (sheet + turn) to approximately $20 \%$. At $65{ }^{\circ} \mathrm{C}$, helicity decreased to $40 \%$ with increased beta content to $31 \%$ and disorder to almost $30 \%$. At $85{ }^{\circ} \mathrm{C}$, helicity decreased to approximately $1 / 4$ with an increase in beta content to $40 \%$, and $34 \%$ disorder. The $\theta_{222} / \theta_{208}$ ratios were greater than 1 at temperatures up to $45^{\circ} \mathrm{C}$ (Table S3), but these values may have been influenced by the presence of the beta secondary structure. Ratios were less than 1 at temperatures above $65^{\circ} \mathrm{C}$.

At acidic $\mathrm{pH}$, approximately $80 \%$ helical content with marginal disorder was observed from 5 to $45^{\circ} \mathrm{C}$, with decreased helical content and concomitant increase in beta and disorder content seen 
at $65{ }^{\circ} \mathrm{C}$, although the change in spectral appearance seems relatively minor (Figure $3 \mathrm{~d}$ ). The major spectral change at $85^{\circ} \mathrm{C}$ corresponds to a helicity reduction to approximately $20 \%$ with increased beta and disorder contents to approximately $40 \%$ each. The $\theta_{222} / \theta_{208}$ ratios suggest CC formation at least up to $65^{\circ} \mathrm{C}$, which was lost by $85^{\circ} \mathrm{C}$ (Table S4).

\subsection{Dynamic Light Scattering and Zeta Potential}

Dynamic light scattering (DLS) was used to assess the size and aggregation state of cl-Par-4 under varying conditions. The measured stokes radius $\left(\mathrm{R}_{\mathrm{s}}\right)$ values were $483 \mathrm{~nm}$ at $\mathrm{pH} 7$ and $339 \mathrm{~nm}$ at $\mathrm{pH} 10$, while measurements at $\mathrm{pH} 4$ gave an $\mathrm{R}_{\mathrm{s}}$ of $43 \mathrm{~nm}$ (Figure $4 \mathrm{a}$ ). DLS measurements were also recorded under denaturing conditions of $0.1 \%$ SDS at $\mathrm{pH} 7$, producing an $\mathrm{R}_{\mathrm{s}}$ of $28.3 \mathrm{~nm}$. The experimental $\mathrm{pI}$ was determined by zeta potential measurements (Figure $4 \mathrm{~b}$ ). Zeta potential decreased from +15.4 to $-20.01 \mathrm{mV}$ when $\mathrm{pH}$ was increased from 4-10. The experimental pI was determined to be $\mathrm{pH}$ 5.35, consistent with the theoretical $\mathrm{pI}$ of 5.39. Figure $4 \mathrm{c}$ shows the $\mathrm{R}_{\mathrm{s}}$ measurements over the course of seven days at $\mathrm{pH} 4,7$, and 10 . At $\mathrm{pH} 7$ and 10, the $\mathrm{R}_{\mathrm{s}}$ changed substantially over seven days with significant variation in measured $R_{s}$. There was little variation in acidic conditions, with $R_{s}$ ranging from 41.8-45.0 nm over time.

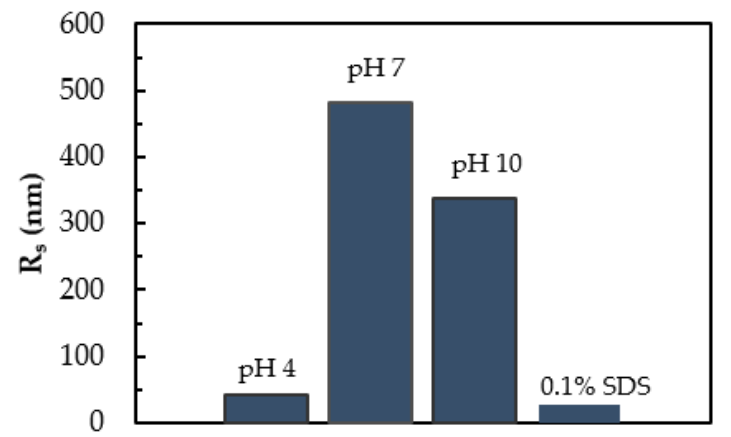

(a)

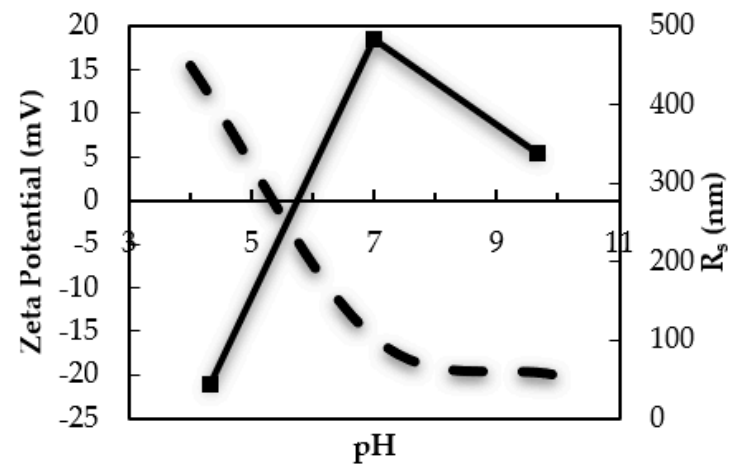

(b)

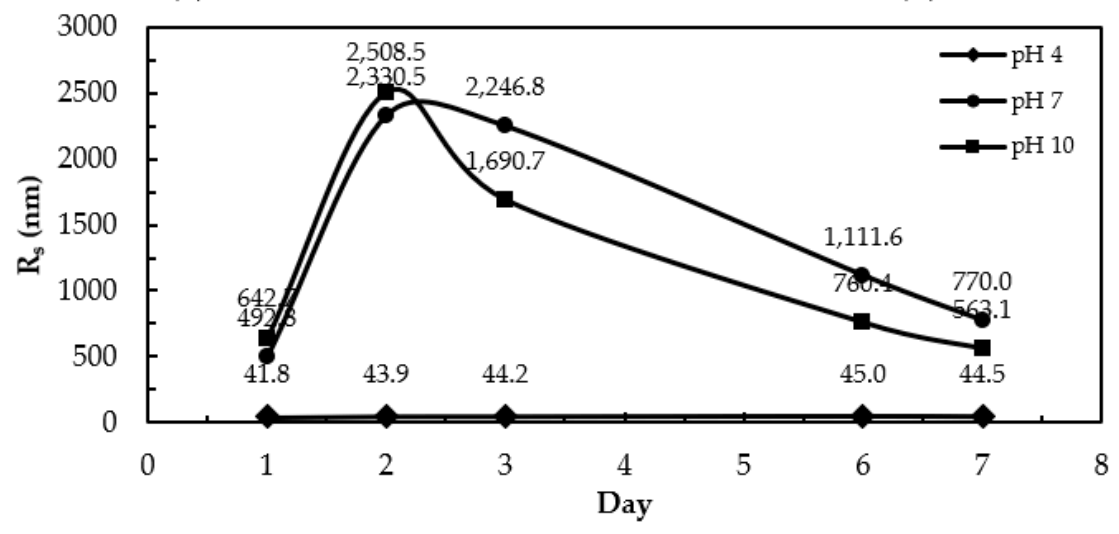

(c)

Figure 4. (a) Measured $\mathrm{R}_{\mathrm{s}}$ of cl-Par-4 under native and denaturing conditions by Dynamic Light Scattering (DLS). (b) Relationship of zeta potential (dashed) to $\mathrm{pH}$ and $\mathrm{R}_{\mathrm{S}}$ (solid line). (c) Measured $\mathrm{R}_{\mathrm{S}}$ over seven days at $\mathrm{pH} 4,7$, and 10 .

The $\mathrm{R}_{\mathrm{s}}$ values at $\mathrm{pH} 7$ and 10 indicate aggregation above the $\mathrm{pI}$ of 5.35. A large $\mathrm{R}_{\mathrm{s}}$ can also be indicative of a non-globular or rod-shaped conformation. However, the values here were much larger than expected for a monomeric or dimeric rod. In contrast, the $\mathrm{R}_{\mathrm{s}}$ value at $\mathrm{pH} 4$ did not indicate the presence of large aggregates, and data at acidic $\mathrm{pH}$ were more monodisperse and time-stable than at neutral $\mathrm{pH}$, although the $\mathrm{R}_{\mathrm{s}}$ was still larger than for the sample in SDS. In fact, the Stokes radii of all non-denatured samples, from $\mathrm{pH} 4-10$, were larger than the partially unfolded SDS form, suggesting 
a polymeric state for cl-Par-4 under each of these conditions. At least some of this self-association is mediated by the C-terminal CC dimerization motif.

\subsection{Tertiary Structure by Fluorescence}

Intrinsic fluorescence can be used to monitor the solvent exposure of aromatic amino acids and so provide information regarding tertiary structure [46]. cl-Par-4 has one tyrosine in the SAC domain and four tyrosines in the linker domain. Interestingly, these regions are predicted to be disordered based on DisEMBL and GOR4 analysis [39,40]. Tyrosine was selectively excited at $220 \mathrm{~nm}$. Figure 5a shows the resulting tyrosine emission spectrum from $250-400 \mathrm{~nm}$ at $25^{\circ} \mathrm{C}$ for samples at $\mathrm{pH} 7$ and $\mathrm{pH} 4$. The emission maximum near $310 \mathrm{~nm}$ was considerably more intense at $\mathrm{pH} 4$ than at $\mathrm{pH} 7$.

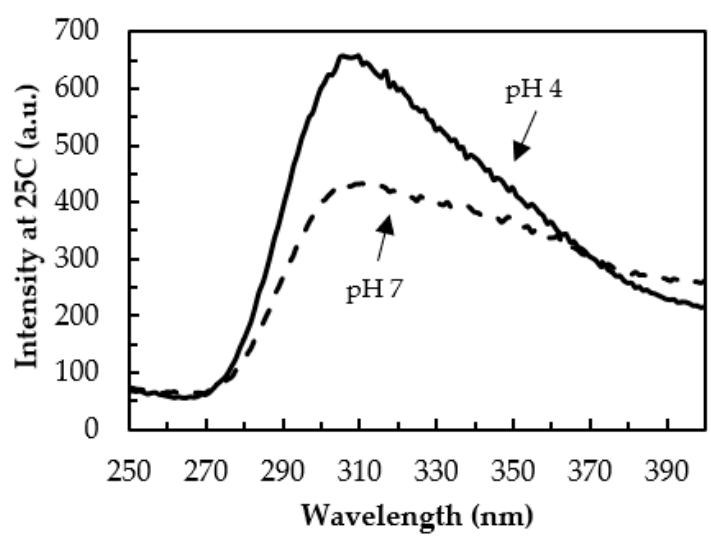

(a)

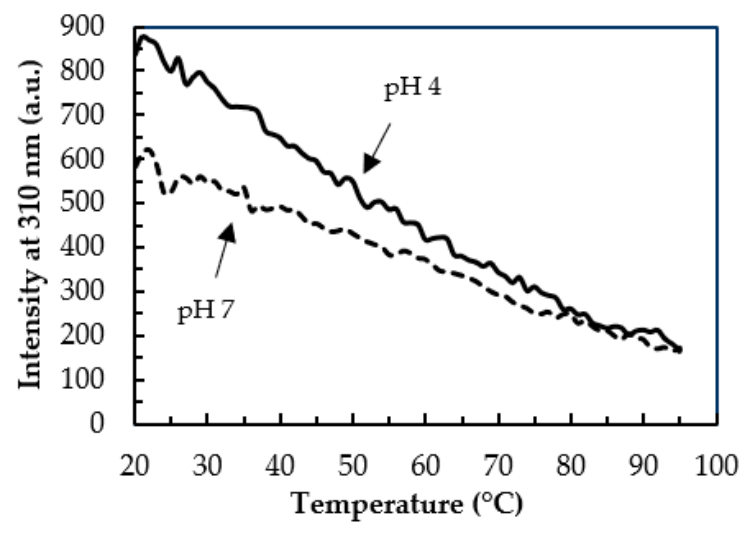

(b)

Figure 5. (a) Intrinsic tyrosine fluorescence at $\mathrm{pH} 4$ (solid) and 7 (dashed) over $250-400 \mathrm{~nm}$ at $25^{\circ} \mathrm{C}$ (b) Thermal denaturation at $\mathrm{pH} 4$ (solid) and 7 (dashed) monitored by fluorescence emission at $310 \mathrm{~nm}$.

Thermal denaturation at $\mathrm{pH} 7$ and $\mathrm{pH} 4$ was also investigated (Figure 5b) by monitoring the tyrosine emission at $310 \mathrm{~nm}$ as the temperature was increased from $20-95^{\circ} \mathrm{C}$. Both samples showed a marked decrease in fluorescence emission with rising temperature. Together, these spectra indicate that at acidic $\mathrm{pH}, \mathrm{cl}-\mathrm{Par}-4$ adopts a fold that protects the tyrosines from solvent exposure, more so than the conformation at neutral $\mathrm{pH}$. However, under both conditions, substantial solvent protection of tyrosine residues exists at low temperatures.

\section{Discussion}

\subsection{Intrinsic Disorder in cl-Par-4}

Disorder-to-order transition plays a major role in IDP functions, such as the regulation of cell signaling and ligand binding [27,47]. Common features of IDPs include reduced sequence complexity, high net charge, and often increased stability at extreme temperature and $\mathrm{pH}[26,47,48]$. This last feature is clearly related to the high content of charged residues, since extreme $\mathrm{pH}$ will change the charge distribution. In most cases, this will reduce the number of charged side chains, thus reducing charge-charge repulsions that inhibit folding of the protein.

Full-length Par-4 has been classified as mostly intrinsically disordered, although it contains a helical CC at its C-terminus [21-23]. However, it has been established that apoptosis is directly triggered by the $25 \mathrm{kDa}$ cl-Par-4 fragment, which is capable of entering the nucleus [30]. This "activated" fragment of Par-4 was studied here, bearing in mind that it derives from the largely disordered full-length protein. DisEMBL disorder prediction showed a high disorder probability in the linker domain and some disorder in the SAC domain, which coincided with regions of low helix propensity 
by GOR4 analysis (Figure 1b,c) [39,40]. Additionally, GOR4 analysis predicted approximately $42 \%$ disorder under physiological conditions (Figure 1c) [40].

Consistent with this prediction, we found evidence for disorder in cl-Par-4. First, cl-Par-4 displayed an apparent molecular weight of $31 \mathrm{kDa}$ via SDS-PAGE analysis, which was approximately $30 \%$ higher than expected (Figure S1). This was consistent with previous studies on the racine Par-4 full length, SAC, and deleted LZ constructs, which each showed apparent molecular weights based on SDS-PAGE, which were at least 30\% higher than the predictions based on the primary structure and experimentally determined via mass spectroscopy [21]. This behavior is due to the unique negatively-charged amino acid composition typical of IDPs, which reduces the affinity of SDS binding, preventing full denaturation and decreasing electrophoretic mobility [26,43,44]. CD (Figure 2a, Table S1) and DLS (Figure 4a) analysis were also consistent with only partial disorder in the presence of SDS. Thermal denaturation (Figure 3, Tables S2 and S3) was better able to unfold cl-Par-4, confirming that a significant degree of structure remains in the presence of the SDS denaturant.

\subsection{Instability at Neutral $\mathrm{pH}$}

At neutral $\mathrm{pH}$, cl-Par-4 shows a mix of order and disorder. CD spectra at $\mathrm{pH} 7$ shows cl-Par-4 to be approximately $50 \%$ helical, $30 \%$ beta, and $20 \%$ disordered (Figure 2) with significant temperature sensitivity (Figure 3). DLS experiments showed large measured $R_{s}$, which varied with time. IDPs have a larger $R_{S}$ than a globular protein of the same molar mass. However, the $R_{S}$ value here was far larger than expected for a disordered monomer, and instead indicates aggregation $[49,50]$. Fluorescence emission spectra indicated the partial protection of tyrosine residues in the SAC and linker domains.

A high $\theta_{222} / \theta_{208}$ ratio indicates $C C$ formation, and hence self-association, although beta content could inflate this ratio. Conformational instability and increased size occurred at all $\mathrm{pH}$ values tested above the experimentally determined pI of 5.35 (Figure 4b). CD spectra showed significantly more helical content at $\mathrm{pH} 5$ than at $\mathrm{pH} 5.5$ or $\mathrm{pH} 6.5$ (Figure 2c). Taken together, the data demonstrated that at $\mathrm{pH}$ above the $\mathrm{pI}$, aggregation, conformational instability, and partial disorder resulted.

Figure 6 shows a helical wheel diagram of the LZ region of Par-4. LZs are a special type of coiled-coil oligomerization motif with leucines in the $d$ position [51-53]. The dashed lines in Figure 6 represent inter-helical interaction between charged residues at the $e$ and $g$ positions. The D-E charge repulsion contributes to the conformational instability observed above the $\mathrm{pI}$, as previously determined for the LZ and CC constructs [22,24,25]. In summary, the disorder and aggregation at $\mathrm{pH}$ above the $\mathrm{pI}$ can be explained via electrostatic repulsion across the LZ dimer interface.

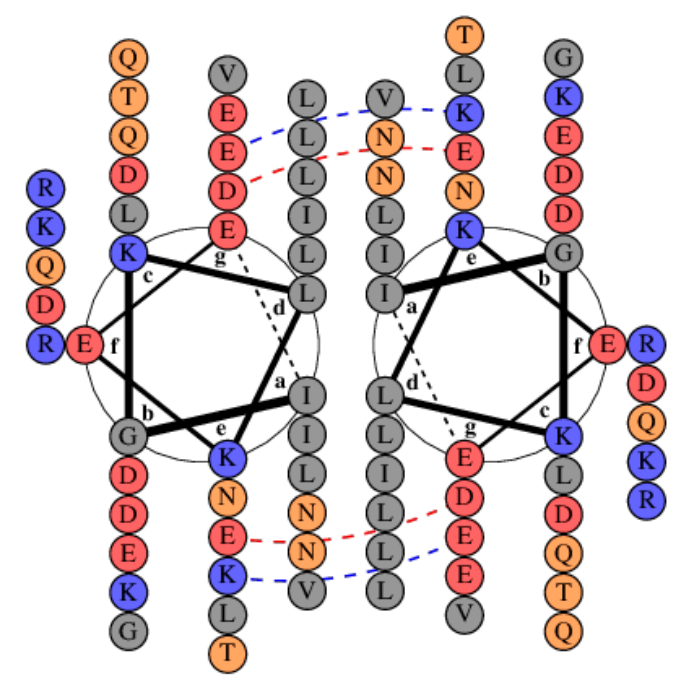

Figure 6. Helical wheel representation of Par-4 leucine zipper parallel dimer (DrawCoil 1.0, Dartmouth College, Hanover, NH, USA). Basic residues are blue and acidic residues are red. The red dashed line represents inter-helical charge repulsion and the blue dashed line represents an inter-helical salt bridge. 


\subsection{Acidic $p H$ Induces folding}

Negative-negative electrostatic repulsion within the cl-Par-4 CC domain is abrogated at low $\mathrm{pH}$ due to partial titration of the acidic side chains involved [24,25]. Due to the associating negative charges, the pKas of the repelling D-E acidic side chains (Figure 6) in the CC domain are expected to be higher than normal and should be somewhere in the range of 5-6. This was consistent with the increased stability seen at $\mathrm{pH} 5$ vs. $\mathrm{pH} 5.5$ and $\mathrm{pH}$ 6.0.

It is for this reason that, at $\mathrm{pH}$ below the $\mathrm{pI}$, the cl-Par-4 helical content was high (approximately $80 \%$ ), and CC formation was evident from $\theta_{222} / \theta_{208}$ ratios, particularly at $\mathrm{pH} 5$ (Figure 2c). DLS showed a monodisperse conformation with an $\mathrm{R}_{\mathrm{s}}$ value intermediate between the largely disordered monomer in SDS and the half-disordered aggregate at neutral $\mathrm{pH}$ (Figure 4). Fluorescence showed significant protection of the tyrosine residues in the SAC and linker domains (Figure 5). Together, these data suggest that at acidic $\mathrm{pH}, \mathrm{cl}-\mathrm{Par}-4$ forms a single, stable conformation of fixed self-association state, with substantial CC and perhaps additional non-coiled helical regions. The amount of helix present requires that at least part of the SAC and linker domains have a helical character.

While CD spectroscopy indicates thermal stability up to at least $65^{\circ} \mathrm{C}$, the $222 \mathrm{~nm}$ band became systematically less intense with increasing temperature (Figure $3 b$ ). This suggests a reduction in CC content at higher temperatures $\left(\theta_{222} / \theta_{208}\right.$ ratios in Table 44$)$. Some IDPs such as nerve growth factor and $\alpha$ s-casein gain structure upon increased temperature $[54,55]$. Our results showed the opposite trend: increased temperature resulted in the partial loss of secondary structure in cl-Par-4, providing further evidence of an ordered structure.

To further assess the conformation at acidic $\mathrm{pH}$, template-based models were generated via GalaxyTBM on the GalaxyWEB server [56]. The racine Par-4 CC crystal structure (pdb 5fiy_A) was used as a template and the remainder of the protein was allowed to fold computationally [23]. An ensemble of five structures was generated and visually inspected for features consistent with the above biophysical results for cl-Par-4 at acidic $\mathrm{pH}$. At least part of the SAC and linker domains must fold under acidic conditions since the CC only comprised approximately $37 \%$ of the protein fragment, while CD analysis indicated approximately $80 \%$ helical content. The structure shown in Figure 7 is representative of the type of conformation that may occur at acidic $\mathrm{pH}$ : a relatively compact conformation with partially helical SAC and linker domains attached to the C-terminal CC.

Interestingly, increased caspase- 3 activation is known to occur during apoptosis due to the release of cysteine proteases from the lysosome, during cytosolic acidification [57-61]. This suggests that cl-Par-4 may be formed under acidic conditions. For subsequent nuclear entry, another protein such as a nuclear import receptor must bind the NLS of cl-Par-4 [5,62,63]. The NLS would likely be accessible in a folded non-aggregated conformation such as that represented in Figure 7, but may not be accessible in the largely disordered aggregate present at neutral $\mathrm{pH}$.

Consistent with this possible mechanism, the Ras association domain family member 2 (RASSF2) tumor suppressor has been shown to bind a cl-Par-4-sized fragment of Par-4, via the NLS [64]. This binding interaction enhances the nuclear localization of the Par-4 fragment, leading to cancer cell apoptosis [64]. In contrast, the NES is most likely masked by homo-dimerization mediated by the CC, preventing the nuclear exit of cl-Par-4 [12]. Taken together, these results indicate that caspase-induced cleavage of Par-4, creating cl-Par-4, simultaneously exposes the cl-Par-4 NLS and sequesters the nuclear export sequence (NES), obligating nuclear localization. The folded conformation shown here is consistent with exposure of the NLS at its N-terminus, and sequestration of the NES within the $\mathrm{CC}$ dimerization domain. Furthermore, we have shown that at acidic $\mathrm{pH}$, aggregation of cl-Par-4 is inhibited, producing a molecular size more consistent with the ability to traverse nuclear pores. 


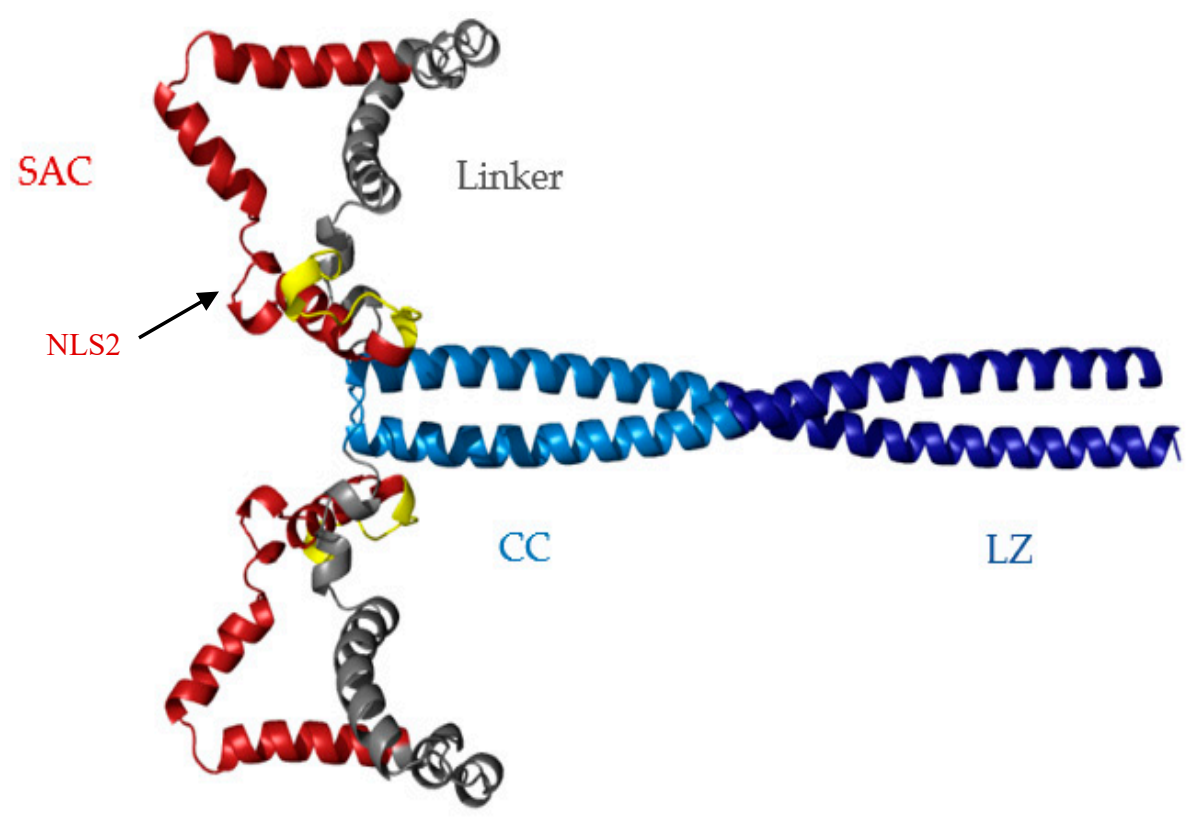

Figure 7. GalaxyWEB model of cl-Par-4 at acidic $\mathrm{pH}$. The N-terminal residues are yellow, the selective for apoptosis induction in cancer cells (SAC) domain with nuclear localization signal 2 (NLS2) is red, the linker region is gray, and coiled coil (CC) is blue. Darker blue is the leucine zipper (LZ) region of the CC. The position of NLS2 is also indicated.

\subsection{Acidic Environments}

Though acidic $\mathrm{pH}$ can induce cl-Par-4 folding in vitro, the physiological relevance of the acid-induced structure of cl-Par-4 remains to be determined. Some clues to the importance of folding at acidic $\mathrm{pH}$ can be obtained through discussion of other proteins with similar characteristics.

First, many in vitro studies have shown IDPs preferentially folding at acidic $\mathrm{pH}[65,66]$. Examples include $\alpha$-synuclein, prothymosin $\alpha$, and the cytoplasmic domain of BAP29 [65,67-69]. The general principle is that acidic $\mathrm{pH}$ can alleviate charge-charge repulsion in IDPs, allowing for stable folding $[26,28,47]$. Other proteins are known to both have a stable structure and to function in an acidic environment. For instance, acid endonucleases function in cell death and have optimal activity as low as $\mathrm{pH} 4.9$ [70,71]. As a second example, dimer formation of the apoptosis-regulating Bcl-2 family proteins is stabilized at $\mathrm{pH} 4$ [72].

Many other proteins, including tumor suppressors, have been detected in lysosomes, endosomes or exosomes, which can be highly acidic. Perhaps the best known example is the p53 tumor suppressor, which can be found in highly acidic lysosomes in human breast cancer cells $[66,73]$. It has been suggested that the $\mathrm{p} 53$ conformation at acidic $\mathrm{pH}$ may function in lysosomal membrane permeabilization, which often occurs in early apoptosis $[66,74]$. The PTEN protein is an example of a tumor suppressor that is transported via exosomes [75]. Exosomes can be used for the intercellular transfer of tumor suppressors, which helps to prevent tumor proliferation [76,77]. Exosome biogenesis occurs through the lysosome-endosome pathway ( $\mathrm{pH} 4-6$ range), a $\mathrm{pH}$ range that is consistent with the acidic $\mathrm{pH}$ in our study [78-84].

Therefore, it is interesting to note that while most studies of Par-4 have focused on intracellular pathways, full length Par-4, along with Par-4 fragments of 33 and 14 kDa (based on SDS-PAGE) have also been found in secreted exosomes (termed apoxosomes) [85]. These fragments have not yet been positively identified, however, the SDS-PAGE-based sizes are consistent with those created by caspase-induced cleavage, including the cl-Par-4 fragment. Additionally, p62 forms a ternary complex with PKC $\zeta$ (protein kinase C) and Par-4 (through the Par-4 C-terminus), helping to regulate the NF- $\mathrm{KB}$ pathway [86]. Interestingly, atypical isoforms of $\mathrm{PKC}$, such as $\mathrm{PKC} \zeta$, co-localize with p62 to late endosomal compartments [86-89], suggesting that Par-4 may also localize to late endosomes. Therefore, 
it is quite plausible that future studies will positively identify cl-Par-4 in these acidic organelles. Additionally, the fact that the typical exosome size is less than $100 \mathrm{~nm}$ [90] suggests that cl-Par-4 under neutral conditions $\left(\mathrm{R}_{\mathrm{s}}>400 \mathrm{~nm}\right)$ may be too large for exosomal transport. However, the folded conformation at acidic $\mathrm{pH}$ would be of a more suitable size. It has also been well documented that the cytosol of cancer cells can become acidic, particularly during apoptotic processes [60,61,70,91-95]. For instance, one study showed apoptotic human histiocytic lymphoma cells with a cytosolic pH of $5.7[73,81]$. While the degree of acidification or alkalination may vary in different tumors, cancer-related acidification of the cytosol, when it does occur, could potentially help to promote IDP folding.

Finally, it should be noted that in vivo folding of cl-Par-4 may be influenced by factors other than $\mathrm{pH}$, including post-translational modification or interactions with other proteins or ions. This could help to reduce the conformational instability observed at neutral $\mathrm{pH}$. However, these factors are not required for the stable folding of cl-Par-4 at acidic $\mathrm{pH}$.

\section{Conclusions}

In summary, the data in the present study demonstrate that folding of the cl-Par-4 tumor suppressor is markedly $\mathrm{pH}$-dependent: cl-Par-4 is partially folded and aggregated at neutral $\mathrm{pH}$, but folds into a non-aggregated, mostly helical conformation at acidic $\mathrm{pH}$. This is the first evidence of structure outside of the CC domain in Par-4, indicating that cl-Par-4, under acidic conditions, should be classified as an ordered, folded protein.

Supplementary Materials: The following are available online at http://www.mdpi.com/2218-273X/8/4/162/s1. Figure S1: SDS-PAGE of cl-Par-4 (25kDa); Table S1: Secondary structure percentages of cl-Par-4 under at pH 4, 7, 10 , and SDS denaturing conditions by deconvolution of the CD spectra; Table S2: Secondary structure percentages

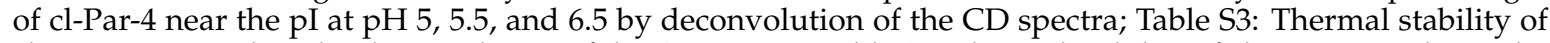
cl-Par-4 at neutral $\mathrm{pH}$ by deconvolution of the CD spectra; Table S4: Thermal stability of cl-Par- 4 at acidic $\mathrm{pH}$ by deconvolution of the CD spectra.

Author Contributions: S.M.P., A.M.C., and K.P. conceived and designed the experiments. K.P. made the cl-Par-4 construct and did test expressions. A.M.C. and M.S.W. prepared and purified protein samples. A.C.Y. helped to establish expression conditions. A.M.C. performed the secondary structure predictions, CD and DLS experiments, and modeling. E.M.R. performed the fluorescence experiments. A.M.C. and E.M.R. did the data analysis. A.M.C. and S.M.P. wrote the manuscript.

Funding: This research was funded by Old Dominion University through startup funds and Program in Undergraduate Research funds to S.M.P., and by Virginia Space Grant Consortium graduate research fellowship to A.M.C.

Acknowledgments: The authors wish to thank Professor Vivek Rangnekar, Professor David Libich, Professor John Cooper, Kory Castro, and John Bedford.

Conflicts of Interest: The authors declare no conflict of interest.

\section{References}

1. Sells, S.F.; Wood, D.P., Jr.; Joshi-Barve, S.S.; Muthukumar, S.; Jacob, R.J.; Crist, S.A.; Humphreys, S.; Rangnekar, V.M. Commonality of the Gene Programs Induced by Effectors of Apoptosis in Androgen-dependent and-independent Prostate Cells. Cell Growt Differ. 1994, 5, 457-466.

2. Sells, S.F.; Han, S.S.; Muthukkumar, S.; Maddiwar, N.; Johnstone, R.; Boghaert, E.; Gillis, D.; Liu, G.; Nair, P.; Monnig, S.; et al. Expression and function of the leucine zipper protein Par-4 in apoptosis. Mol. Cell. Biol. 1997, 17, 3823-3832. [CrossRef] [PubMed]

3. Boghaert, E.; Sells, S.F.; Walid, A.J.; Malone, P.; Williams, N.M.; Weinstein, M.H.; Strange, R.; Rangnekar, V.M. Immunohistochemical analysis of the proapoptotic protein Par-4 in normal rat tissues. Cell Growth Differ. 1997, 8, 881-890. [PubMed]

4. Burikhanov, R.; Zhao, Y.; Goswami, A.; Qiu, S.; Schwarze, S.R.; Rangnekar, V.M. The Tumor Suppressor Par-4 Activates an Extrinsic Pathway for Apoptosis. Cell 2009, 138, 377-388. [CrossRef] [PubMed]

5. El-Guendy, N.; Rangnekar, V.M. Apoptosis by Par-4 in cancer and neurodegenerative diseases. Exp. Cell Res. 2003, 283, 51-66. [CrossRef] 
6. Kögel, D.; Reimertz, C.; Mech, P.; Poppe, M.; Frühwald, M.C.; Engemann, H.; Scheidtmann, K.H.; Prehn, J.H.M. Dlk/ZIP kinase-induced apoptosis in human medulloblastoma cells: Requirement of the mitochondrial apoptosis pathway. Br. J. Cancer 2001, 85, 1801-1808. [CrossRef] [PubMed]

7. Cook, J.; Krishnan, S.; Ananth, S.; Sells, S.F.; Shi, Y.; Walther, M.M.; Linehan, W.M.; Sukhatme, V.P.; Weinstein, M.H.; Rangnekar, V.M. Decreased expression of the pro-apoptotic protein Par-4 in renal cell carcinoma. Oncogene 1999, 18, 1205-1208. [CrossRef]

8. Moreno-Bueno, G.; Fernandez-Marcos, P.J.; Collado, M.; Tendero, M.J.; Rodriguez-Pinilla, S.M.; Garcia-Cao, I.; Hardisson, D.; Diaz-Meco, M.T.; Moscat, J.; Serrano, M.; et al. Inactivation of the Candidate Tumor Suppressor Par-4 in Endometrial Cancer. Cancer Res. 2007, 67, 1927-1934. [CrossRef]

9. Zapata-Benavides, P.; Méndez-Vázquez, J.L.; González-Rocha, T.R.; Zamora-Avila, D.E.; Franco-Molina, M.A.; Garza-Garza, R.; Rodriguez-Padilla, C. Expression of Prostate Apoptosis Response (Par-4) Is Associated with Progesterone Receptor in Breast Cancer. Arch. Med. Res. 2009, 40, 595-599. [CrossRef]

10. Ranganathan, P.; Rangnekar, V.M. Regulation of Cancer Cell Survival by Par-4. Ann. N. Y. Acad. Sci. 2005, 1059, 76-85. [CrossRef]

11. Johnstone, R.W.; Tommerup, N.; Hansen, C.; Vissing, H.; Shi, Y. Mapping of the Human PAWR (par-4) Gene to Chromosome 12q21. Genomics 1998, 53, 241-243. [CrossRef] [PubMed]

12. Chakraborty, M.; Qiu, S.G.; Vasudevan, K.M.; Rangnekar, V.M. Par-4 Drives Trafficking and Activation of Fas and FasL to Induce Prostate Cancer Cell Apoptosis and Tumor Regression. Cancer Res. 2001, 61, 7255-7263. [PubMed]

13. Shrestha-Bhattarai, T.; Rangnekar, V.M. Cancer-selective apoptotic effects of extracellular and intracellular Par-4. Oncogene 2010, 29, 3873-3880. [CrossRef] [PubMed]

14. Lee, A.S. GRP78 Induction in Cancer: Therapeutic and Prognostic Implications. Cancer Res. 2007, 67, 3496-3499. [CrossRef] [PubMed]

15. Johnstone, R.W.; See, R.H.; Sells, S.F.; Wang, J.; Muthukkumar, S.; Englert, C.; Haber, D.A.; Licht, J.D.; Sugrue, S.P.; Roberts, T.; et al. A novel repressor, par-4, modulates transcription and growth suppression functions of the Wilms' tumor suppressor WT1. Mol. Cell. Biol. 1996, 16, 6945-6956. [CrossRef] [PubMed]

16. Gurumurthy, S.; Goswami, A.; Vasudevan, K.M.; Rangnekar, V.M. Phosphorylation of Par-4 by Protein Kinase A Is Critical for Apoptosis. Mol. Cell. Biol. 2005, 25, 1146-1161. [CrossRef] [PubMed]

17. El-Guendy, N.; Zhao, Y.; Gurumurthy, S.; Burikhanov, R.; Rangnekar, V.M. Identification of a Unique Core Domain of Par-4 Sufficient for Selective Apoptosis Induction in Cancer Cells. Mol. Cell. Biol. 2003, 23, 5516-5525. [CrossRef] [PubMed]

18. Goswami, A.; Burikhanov, R.; de Thonel, A.; Fujita, N.; Goswami, M.; Zhao, Y.; Eriksson, J.E.; Tsuruo, T.; Rangnekar, V.M. Binding and Phosphorylation of Par-4 by Akt Is Essential for Cancer Cell Survival. Mol. Cell 2005, 20, 33-44. [CrossRef]

19. Zhao, Y.; Burikhanov, R.; Qiu, S.; Lele, S.M.; Jennings, C.D.; Bondada, S.; Spear, B.; Rangnekar, V.M. Cancer Resistance in Transgenic Mice Expressing the SAC Module of Par-4. Cancer Res. 2007, 67, 9276-9285. [CrossRef]

20. Goswami, A.; Qiu, S.; Dexheimer, T.S.; Ranganathan, P.; Burikhanov, R.; Pommier, Y.; Rangnekar, V.M. Par-4 Binds to Topoisomerase 1 and Attenuates Its DNA Relaxation Activity. Cancer Res. 2008, 68, 6190-6198. [CrossRef]

21. Libich, D.S.; Schwalbe, M.; Kate, S.; Venugopal, H.; Claridge, J.K.; Edwards, P.J.; Dutta, K.; Pascal, S.M. Intrinsic disorder and coiled-coil formation in prostate apoptosis response factor 4. FEBS J. 2009, 276, 3710-3728. [CrossRef] [PubMed]

22. Schwalbe, M.; Dutta, K.; Libich, D.S.; Venugopal, H.; Claridge, J.K.; Gell, D.A.; Mackay, J.P.; Edwards, P.J.; Pascal, S.M. Two-state conformational equilibrium in the Par-4 leucine zipper domain. Proteins 2010, 78, 2433-2449. [CrossRef] [PubMed]

23. Tiruttani Subhramanyam, U.K.; Kubicek, J.; Eidhoff, U.B.; Labahn, J. Structural basis for the regulatory interactions of proapoptotic Par-4. Cell Death Differ. 2017, 24, 1540-1547. [CrossRef] [PubMed]

24. Dutta, K.; Alexandrov, A.; Huang, H.; Pascal, S.M. pH-induced folding of an apoptotic coiled coil. Protein Sci. 2001, 10, 2531-2540. [CrossRef] [PubMed]

25. Dutta, K.; Engler, F.A.; Cotton, L.; Alexandrov, A.; Bedi, G.S.; Colquhoun, J.; Pascal, S.M. Stabilization of a pH-sensitive apoptosis-linked coiled coil through single point mutations. Protein Sci. 2003, 12, 257-265. [CrossRef] [PubMed] 
26. Tompa, P. Intrinsically unstructured proteins. Trends Biochem. Sci. 2002, 27, 527-533. [CrossRef]

27. Wright, P.E.; Dyson, H.J. Intrinsically unstructured proteins: Re-assessing the protein structure-function paradigm. J. Mol. Biol. 1999, 293, 321-331. [CrossRef] [PubMed]

28. Uversky, V.N.; Gillespie, J.R.; Fink, A.L. why are "natively unfolded" proteins unstructured under physiologic conditions? Proteins 2000, 41, 415-427. [CrossRef]

29. Uversky, V.N.; Oldfield, C.J.; Dunker, A.K. Intrinsically Disordered Proteins in Human Diseases: Introducing the D2 Concept. Ann. Rev. Biophys. 2008, 37, 215-246. [CrossRef]

30. Chaudhry, P.; Singh, M.; Parent, S.; Asselin, E. Prostate Apoptosis Response 4 (Par-4), a Novel Substrate of Caspase-3 during Apoptosis Activation. Mol. Cell. Biol. 2012, 32, 826-839. [CrossRef]

31. Thayyullathil, F.; Pallichankandy, S.; Rahman, A.; Kizhakkayil, J.; Chathoth, S.; Patel, M.; Galadari, S. Caspase-3 mediated release of SAC domain containing fragment from Par-4 is necessary for the sphingosine-induced apoptosis in Jurkat cells. J. Mol. Signal 2013, 8, 2. [CrossRef] [PubMed]

32. Chen, X.; Sahasrabuddhe, A.A.; Szankasi, P.; Chung, F.; Basrur, V.; Rangnekar, V.M.; Pagano, M.; Lim, M.S.; Elenitoba-Johnson, K.S. Fbxo45-mediated degradation of the tumor-suppressor Par-4 regulates cancer cell survival. Cell Death Differ. 2014, 21, 1535-1545. [CrossRef] [PubMed]

33. Hebbar, N.; Burikhanov, R.; Shukla, N.; Qiu, S.; Zhao, Y.; Elenitoba-Johnson, K.S.J.; Rangnekar, V.M. A Naturally Generated Decoy of the Prostate Apoptosis Response-4 Protein Overcomes Therapy Resistance in Tumors. Cancer Res. 2017, 77, 4039-4050. [CrossRef] [PubMed]

34. Treude, F.; Kappes, F.; Fahrenkamp, D.; Müller-Newen, G.; Dajas-Bailador, F.; Krämer, O.H.; Lüscher, B.; Hartkamp, J. Caspase-8-mediated PAR-4 cleavage is required for TNF $\alpha$-induced apoptosis. Oncotarget 2014, 5, 2988-2998. [CrossRef]

35. Brasseur, K.; Fabi, F.; Adam, P.; Parent, S.; Lessard, L.; Asselin, E. Post-translational regulation of the cleaved fragment of Par-4 in ovarian and endometrial cancer cells. Oncotarget 2016, 7, 36971-36987. [CrossRef] [PubMed]

36. Cheema, S.K.; Mishra, S.K.; Rangnekar, V.M.; Tari, A.M.; Kumar, R.; Lopez-Berestein, G. Par-4 Transcriptionally Regulates Bcl-2 through a WT1-binding Site on the bcl-2 Promoter. J. Biol. Chem. 2003, 278, 19995-20005. [CrossRef] [PubMed]

37. Alexandrov, A.; Dutta, K.; Pascal, S.M. MBP Fusion Protein with a Viral Protease Cleavage Site: One-Step Cleavage/Purification of Insoluble Proteins. Biotechniques 2001, 30, 1194-1198. [CrossRef]

38. Whitmore, L.; Wallace, B.A. DICHROWEB, an online server for protein secondary structure analyses from circular dichroism spectroscopic data. Nucleic Acids Res. 2004, 32, W668-W673. [CrossRef]

39. Linding, R.; Jensen, L.J.; Diella, F.; Bork, P.; Gibson, T.J.; Russell, R.B. Protein Disorder Prediction: Implications for Structural Proteomics. Structure 2003, 11, 1453-1459. [CrossRef]

40. Garnier, J.; Gibrat, J.-F.; Robson, B. GOR method for predicting protein secondary structure from amino acid sequence. Methods Enzymol. 1996, 266, 540-553.

41. Dyer, K.F. The Quiet Revolution: A New Synthesis of Biological Knowledge. J. Biol. Educ. 1971, 5, 15-24. [CrossRef]

42. King, J.L.; Jukes, T.H. Non-Darwinian Evolution. Science 1969, 164, 788-798. [CrossRef] [PubMed]

43. Receveur-Bréchot, V.; Bourhis, J.M.; Uversky, V.N.; Canard, B.; Longhi, S. Assessing protein disorder and induced folding. Proteins 2006, 62, 24-45. [CrossRef] [PubMed]

44. Hu, C.C.; Ghabrial, S.A. The conserved, hydrophilic and arginine-rich N-terminal domain of cucumovirus coat proteins contributes to their anomalous electrophoretic mobilities in sodium dodecylsulfate-polyacrylamide gels. J. Virol. Methods 1995, 55, 367-379. [CrossRef]

45. Cooper, T.M.; Woody, R.W. The effect of conformation on the CD of interacting helices: A theoretical study of tropomyosin. Biopolymers 1990, 30, 657-676. [CrossRef]

46. Teale, F.W.J. The ultraviolet fluorescence of proteins in neutral solution. Biochem. J. 1960, 76, 381-388. [CrossRef] [PubMed]

47. Dunker, A.K.; Lawson, J.D.; Brown, C.J.; Williams, R.M.; Romero, P.; Oh, J.S.; Oldfield, C.J.; Campen, A.M.; Ratliff, C.M.; Hipps, K.W.; et al. Intrinsically disordered protein. J. Mol. Graph. Model. 2001, 19, $26-59$. [CrossRef]

48. Uversky, V.N. Natively unfolded proteins: A point where biology waits for physics. Protein Sci. 2002, 11, 739-756. [CrossRef] 
49. Tcherkasskaya, O.; Uversky, V.N. Denatured collapsed states in protein folding: Example of apomyoglobin. Proteins 2001, 44, 244-254. [CrossRef]

50. Uversky, V.N. Use of fast protein size-exclusion liquid chromatography to study the unfolding of proteins which denature through the molten globule. Biochemistry 1993, 32, 13288-13298. [CrossRef]

51. Burkhard, P.; Stetefeld, J.; Strelkov, S.V. Coiled coils: A highly versatile protein folding motif. Trends Cell Biol. 2001, 11, 82-88. [CrossRef]

52. Vinson, C.; Myakishev, M.; Acharya, A.; Mir, A.A.; Moll, J.R.; Bonovich, M. Classification of Human B-ZIP Proteins Based on Dimerization Properties. Mol. Cell. Biol. 2002, 22, 6321-6335. [CrossRef] [PubMed]

53. Murre, C.; McCaw, P.S.; Baltimore, D. A new DNA binding and dimerization motif in immunoglobulin enhancer binding, daughterless, MyoD, and myc proteins. Cell 1989, 56, 777-783. [CrossRef]

54. Timm, D.E.; Vissavajjhala, P.; Ross, A.H.; Neet, K.E. Spectroscopic and chemical studies of the interaction between nerve growth factor (NGF) and the extracellular domain of the low affinity NGF receptor. Protein Sci. 1992, 1, 1023-1031. [CrossRef] [PubMed]

55. Kim, T.D.; Ryu, H.J.; Cho, H.I.; Yang, C.H.; Kim, J. Thermal Behavior of Proteins: Heat-Resistant Proteins and Their Heat-Induced Secondary Structural Changes. Biochemistry 2000, 39, 14839-14846. [CrossRef]

56. Ko, J.; Park, H.; Heo, L.; Seok, C. GalaxyWEB server for protein structure prediction and refinement. Nucleic Acids Res. 2012, 40, W294-W297. [CrossRef]

57. Roy, S.; Bayly, C.I.; Gareau, Y.; Houtzager, V.M.; Kargman, S.; Keen, S.L.; Rowland, K.; Seiden, I.M.; Thornberry, N.A.; Nicholson, D.W. Maintenance of caspase-3 proenzyme dormancy by an intrinsic "safety catch" regulatory tripeptide. Proc. Natl. Acad. Sci. USA 2001, 98, 6132-6137. [CrossRef]

58. Park, H.J.; Lyons, J.C.; Ohtsubo, T.; Song, C.W. Acidic environment causes apoptosis by increasing caspase activity. Br. J. Cancer 1999, 80, 1892-1897. [CrossRef]

59. Johansson, A.C.; Steen, H.; Ollinger, K.; Roberg, K. Cathepsin D mediates cytochrome c release and caspase activation in human fibroblast apoptosis induced by staurosporine. Cell Death Differ. 2003, 10, 1253-1259. [CrossRef]

60. Matsuyama, S.; Llopis, J.; Deveraux, Q.L.; Tsien, R.Y.; Reed, J.C. Changes in intramitochondrial and cytosolic pH: Early events that modulate caspase activation during apoptosis. Nat. Cell Biol. 2000, 2, 318-325. [CrossRef]

61. Segal, M.S.; Beem, E. Effect of $\mathrm{pH}$, ionic charge, and osmolality on cytochromec-mediated caspase-3 activity. Am. J. Physiol. Cell Physiol. 2001, 281, C1196-C1204. [CrossRef] [PubMed]

62. Freitas, N.; Cunha, C. Mechanisms and signals for the nuclear import of proteins. Curr. Genomics 2009, 10, 550-557. [CrossRef] [PubMed]

63. Silver, P.A. How proteins enter the nucleus. Cell 1991, 64, 489-497. [CrossRef]

64. Donninger, H.; Hesson, L.; Vos, M.; Beebe, K.; Gordon, L.; Sidransky, D.; Liu, J.W.; Schlegel, T.; Payne, S.; Hartmann, A.; et al. The Ras Effector RASSF2 Controls the PAR-4 Tumor Suppressor. Mol. Cell. Biol. 2010, 30, 2608-2620. [CrossRef] [PubMed]

65. Quistgaard, E.M.; Low, C.; Moberg, P.; Guettou, F.; Maddi, K.; Nordlund, P. Structural and Biophysical Characterization of the Cytoplasmic Domains of Human BAP29 and BAP31. PLoS ONE 2013, 8, e71111. [CrossRef] [PubMed]

66. Ano Bom, A.P.D.; Freitas, M.S.; Moreire, F.S.; Ferraz, D.; Sanches, D.; Gomes, A.M.O.; Valente, A.P.; Cordeiro, Y.; Silva, J.L. The p53 Core Domain Is a Molten Globule at Low pH: functional implications of a partially unfolded structure. J. Biol. Chem. 2010, 285, 2857-2866. [CrossRef] [PubMed]

67. Uversky, V.N.; Gillespie, J.R.; Millett, I.S.; Khodyakova, A.V.; Vasiliev, A.M.; Chernovskaya, T.V.; Vasilenko, R.N.; Kozlovskaya, G.D.; Dolgikh, D.A.; Fink, A.L.; et al. Natively Unfolded Human Prothymosin $\alpha$ Adopts Partially Folded Collapsed Conformation at Acidic pH. Biochemistry 1999, 38, 15009-15016. [CrossRef]

68. Uversky, V.N.; Li, J.; Fink, A.L. Evidence for a Partially Folded Intermediate in $\alpha$-Synuclein Fibril Formation. J. Biol. Chem. 2001, 276, 10737-10744. [CrossRef]

69. Weinreb, P.H.; Zhen, W.; Poon, A.W.; Conway, K.A.; Lansbury, P.T.Jr. NACP, A Protein Implicated in Alzheimer's Disease and Learning, Is Natively Unfolded. Biochemistry 1996, 35, 13709-13715. [CrossRef]

70. Gottlieb, R.A.; Nordberg, J.; Skowronski, E.; Babior, B.M. Apoptosis induced in Jurkat cells by several agents is preceded by intracellular acidification. Proc. Natl. Acad. Sci. USA 1996, 93, 654-658. [CrossRef] 
71. Sharma, K.; Srikant, C.B. G Protein Coupled Receptor Signaled Apoptosis Is Associated with Activation of a Cation Insensitive Acidic Endonuclease and Intracellular Acidification. Biochem. Biophys. Res. Commun. 1998, 242, 134-140. [CrossRef] [PubMed]

72. Xie, Z.; Schendel, S.; Matsuyama, S.; Reed, J.C. Acidic pH Promotes Dimerization of Bcl-2 Family Proteins. Biochemistry 1998, 37, 6410-6418. [CrossRef] [PubMed]

73. Nilsson, C.; Johansson, U.; Johansson, A.C.; Kågedal, K.; Ollinger, K. Cytosolic acidification and lysosomal alkalinization during TNF- $\alpha$ induced apoptosis in U937 cells. Apoptosis 2006, 11, 1149-1159. [CrossRef] [PubMed]

74. Yuan, X.-M.; Wei, L.; Helge, D.; Joseph, L.; Rachel, K.; Leo, S.; Brunk, U.T. Lysosomal destabilization in p53-induced apoptosis. Proc. Natl. Acad. Sci. USA 2002, 99, 6286-6291. [CrossRef] [PubMed]

75. Putz, U.; Howitt, J.; Doan, A.; Goh, C.P.; Low, L.H.; Silke, J.; Tan, S.S. The Tumor Suppressor PTEN Is Exported in Exosomes and Has Phosphatase Activity in Recipient Cells. Sci. Signal. 2012, 5, ra70. [CrossRef] [PubMed]

76. Parolini, I.; Federici, C.; Raggi, C.; Lugini, L.; Palleschi, S.; De Milito, A.; Coscia, C.; Iessi, E.; Logozzi, M.; Molinari, A.; et al. Microenvironmental $\mathrm{pH}$ is a key factor for exosome traffic in tumor cells. J. Biol. Chem. 2009, 284, 34211-34222. [CrossRef] [PubMed]

77. Azmi, A.S.; Bao, B.; Sarkar, F.H. Exosomes in cancer development, metastasis, and drug resistance: A comprehensive review. Cancer Metastasis Rev. 2013, 32, 623-642. [CrossRef]

78. Février, B.; Raposo, G. Exosomes: Endosomal-derived vesicles shipping extracellular messages. Curr. Opin. Cell Biol. 2004, 16, 415-421. [CrossRef]

79. Kowal, J.; Tkach, M.; Théry, C. Biogenesis and secretion of exosomes. Curr. Opin. Cell Biol. 2014, 29, 116-125. [CrossRef]

80. Colombo, M.; Raposo, G.; Théry, C. Biogenesis, Secretion, and Intercellular Interactions of Exosomes and Other Extracellular Vesicles. Annu. Rev. Cell Dev. Biol. 2014, 30, 255-289. [CrossRef]

81. Nilsson, C.; Kågedal, K.; Johansson, U.; Ollinger, K. Analysis of cytosolic and lysosomal pH in apoptotic cells by flow cytometry. Methods Cell Sci. 2004, 25, 185-194. [CrossRef]

82. Mellman, I.; Fuchs, R.; Helenius, A. Acidification of the Endocytic and Exocytic Pathways. Annu. Rev. Biochem. 1986, 55, 663-700. [CrossRef] [PubMed]

83. Tycko, B.; Maxfield, F.R. Rapid acidification of endocytic vesicles containing $\alpha 2$-macroglobulin. Cell 1982, 28, 643-651. [CrossRef]

84. Van Renswoude, J.; Bridges, K.R.; Harford, J.B.; Klausner, R.D. Receptor-mediated endocytosis of transferrin and the uptake of fe in K562 cells: Identification of a nonlysosomal acidic compartment. Proc. Natl. Acad. Sci. USA 1982, 79, 6186-6190. [CrossRef] [PubMed]

85. Wang, G.; Dinkins, M.; He, Q.; Zhu, G.; Poirier, C.; Campbell, A.; Mayer-Proschel, M.; Bieberich, E. Astrocytes Secrete Exosomes Enriched with Proapoptotic Ceramide and Prostate Apoptosis Response 4 (PAR-4): POTENTIAL MECHANISM OF APOPTOSIS INDUCTION IN ALZHEIMER DISEASE (AD). J. Biol. Chem. 2012, 287, 21384-21395. [CrossRef] [PubMed]

86. Chang, S.; Kim, J.H.; Shin, J. p62 forms a ternary complex with PKC $\zeta$ and PAR-4 and antagonizes PAR-4-induced PKC $\zeta$ inhibition. FEBS Letters 2002, 510, 57-61. [CrossRef]

87. Sanchez, P.; De Carcer, G.; Sandoval, I.V.; Moscat, J.; Diaz-Meco, M.T. Localization of Atypical Protein Kinase C Isoforms into Lysosome-Targeted Endosomes through Interaction with p62. Mol. Cell. Biol. 1998, 18, 3069-3080. [CrossRef]

88. Diering, G.H.; Numata, M. Endosomal pH in neuronal signaling and synaptic transmission: Role of $\mathrm{Na}(+) / \mathrm{H}(+)$ exchanger NHE5. Front. Physiol. 2014, 4, 412. [CrossRef]

89. Díaz-Meco, M.T.; Municio, M.M.; Frutos, S.; Sanchez, P.; Lozano, J.; Sanz, L.; Moscat, J. The Product of par-4, a Gene Induced during Apoptosis, Interacts Selectively with the Atypical Isoforms of Protein Kinase C. Cell 1996, 86, 777-786. [CrossRef]

90. Denzer, K.; Kleijmeer, M.J.; Heijnen, H.F.; Stoorvogel, W.; Geuze, H.J. Exosome: From internal vesicle of the multivesicular body to intercellular signaling device. J. Cell Sci. 2000, 113, 3365-3374.

91. Warburg, O. On the Origin of Cancer Cells. Science 1956, 123, 309-314. [CrossRef] [PubMed]

92. Griffiths, J.R. Are cancer cells acidic? Br. J. Cancer 1991, 64, 425-427. [CrossRef] [PubMed] 
93. Li, J.; Eastman, A. Apoptosis in an Interleukin-2-dependent Cytotoxic T Lymphocyte Cell Line Is Associated with Intracellular Acidification: ROLE OF THE Na/H-ANTIPORT. J. Biol. Chem. 1995, 270, 3203-3211. [CrossRef] [PubMed]

94. Matsuyama, S.; Reed, J.C. Mitochondria-dependent apoptosis and cellular pH regulation. Cell Death Differ. 2000, 7, 1155. [CrossRef] [PubMed]

95. Thangaraju, M.; Sharma, K.; Leber, B.; Andrews, D.W.; Shen, S.H.; Srikant, C.B. Regulation of Acidification and Apoptosis by SHP-1 and Bcl-2. J. Biol. Chem. 1999, 274, 29549-29557. [CrossRef] [PubMed]

(C) 2018 by the authors. Licensee MDPI, Basel, Switzerland. This article is an open access article distributed under the terms and conditions of the Creative Commons Attribution (CC BY) license (http:/ / creativecommons.org/licenses/by/4.0/). 